\title{
Prevalence of Overweight and Obesity among Primary Healthcare Workers In Perak, Malaysia
}

\author{
Low Pei Kit ${ }^{a}$, Hazizi Abu Saad ${ }^{a, c}$, Rosita Jamaluddin ${ }^{a}$, Chee Huei Phing ${ }^{b}$ \\ aDepartment of Nutrition and Dietetics, Faculty of Medicine and Health Sciences, Universiti Putra Malaysia, \\ 43400 Serdang, Selangor, Malaysia \\ ${ }^{\mathrm{b}}$ Department of Biomedical Science, Faculty of Science, Universiti Tunku Abdul Rahman, 31900 Kampar, \\ Perak, Malaysia \\ 'Sports Academy, Universiti Putra Malaysia, 43400 Serdang, Selangor, Malaysia
}

\section{ABSTRACT}

Introduction: Overweight and obesity has been emerging as one of the most common and preventable nutritional problems worldwide. In $2016,39 \%$ and $13 \%$ of the adult population worldwide was classified as overweight and obese, respectively. Materials and Methods: We conducted a cross-sectional study at 12 selected health clinics in Perak, Malaysia, and we used multi-stage cluster random sampling to determine the prevalence of overweight and obesity among the primary healthcare workers and the associate factors of obesity indices. Each respondent was required to complete a self-administered questionnaire on their sociodemographic characteristics. In addition, we took anthropometric measurements, including height, weight, BMI, waist circumference, and body fat percentage, of the participants. Results: We recruited 261 primary healthcare workers. Overall, $49.9 \%$ of the healthcare workers were overweight or obese, $51.0 \%$ were at risk of having abdominal obesity, and $79.6 \%$ had a high body fat percentages. Age and self-reported health status were significantly associated with all the obesity indices. Educational level showed significant association with BMI and waist circumference, while occupational status showed an association only with BMI. Older age and professionals were predictors for high obesity indices. Conclusion: The prevalence of obesity among the primary healthcare workers was higher than among the general population. An immediate intervention programme is needed to reduce the prevalence of overweight and obesity among primary healthcare workers.

KEYWORDS: Obesity, BMI, waist circumference, body fat percentage, healthcare workers

\section{INTRODUCTION}

As a middle-income country, Malaysia is now experiencing rapid urbanisation and industrialisation, which have brought significant changes to the lifestyle and dietary patterns of Malaysians. ${ }^{1}$ Apart from its own culinary diversity originating from different ethnicities, the introduction of modern fusion foods has transformed the Malaysian diet from plant-based products with low calories to a diet rich in calories, fats, and sugars. ${ }^{2}$ These tremendous developments over the past few decades are now

Corresponding author

Assoc. Prof. Dr. Hazizi Abu Saad

Department of Nutrition and Dietetics,

Faculty of Medicine and Health Sciences,

Universiti Putra Malaysia,

43400 UPM Serdang, Selangor.

Tel No : +60389472434

Email : hazizi@upm.edu.my causing a "double burden of malnutrition" crisis among Malaysians, especially concerning obesity, which challenging the health sector of Malaysia $^{3}$ because obesity is causing many health problems.

Obesity is defined as a state where excessive fat has accumulated in the body and has jeopardised health. ${ }^{4}$ Cardiovascular diseases (CVD) such as heart disease and stroke, type 2 diabetes mellitus, musculoskeletal disorders, hypertension, and some cancers are the consequences of obesity. ${ }^{5,6}$ In 2016, the worldwide prevalence of overweight and obesity was $39.0 \%$ and $13.0 \%$, respectively. ${ }^{6}$ In Malaysia, population-based surveys (the 2015 National Health and Morbidity Survey [NHMS] and the Malaysian Adults Nutrition Survey [MANS]) showed a high percentage of Malaysian adults being overweight (50.9\%) and obese $(47.7 \%)^{7,8}$ 
Despite the fact that overweight and obesity have been identified as a serious health and social problem, studies on the prevalence of overweight and obesity among the healthcare workers in Malaysia are still limited. Only one study has been conducted in Selangor, Malaysia, regarding primary healthcare workers. The findings showed that $46.1 \%$ of respondents were overweight or obese. Sociodemographic characteristics such as income and educational level were significantly associated with obesity. ${ }^{9}$

Healthcare workers are responsible for protecting and enhancing the health of the community. ${ }^{10}$ They should always be physically fit to project the right image of healthy living and body weight to the public. Unfortunately, various studies have reported a high prevalence of overweight and obesity among healthcare workers, especially in African regions (where more than $70 \%$ of the healthcare workers were overweight or obese). ${ }^{11-15}$ In addition, studies also show that not every healthcare worker succeeds in promoting health. Problems faced by the healthcare workers included low confidence and a lack of knowledge to diagnose obesity and deliver weight management advice to their patients. ${ }^{16,17}$

Various obesity-related anthropometric indices have been suggested for evaluating obesity, including body mass index (BMI), waist circumference, waist-hip ratio, waist-to-height ratio, and body fat percentage. ${ }^{18-20}$ However, although most studies depend solely on BMI, it has been found to possess significant limitations, bringing doubt to its reliability. ${ }^{2,6,21}$ Therefore, this study uses waist circumference and body fat percentage in addition to BMI. Such variables have not been measured in previous studies among healthcare workers in Malaysia.

In this study, we sought to determine the prevalence of overweight and obesity among the primary healthcare workers in Perak and to investigate the factors associated with the obesity indices.

\section{METHODOLOGY}

As health clinics are one of the most important places for the dissemination of health practices, the locations for this study included all the health clinics in Perak. Based on random sampling, we conducted a cross-sectional study in 12 health clinics from the
Kinta District, Kuala Kangsar District, and Perak Tengah District from August 2017 to April 2018. This study was approved by the National Medical Research Registry (the Medical Research and Ethics Committee of Ministry of Health Malaysia; Reference number: NMRR-16-2728-33440) and the Ethics Committee for Research Involving Human Subjects (Universiti Putra Malaysia; Reference number: UPM/TNCPI/ RMC/1.4.18.2). In addition, the Perak State Health Department gave permission to carry out the study and collect data from the selected health clinics.

The subject criteria of this study included being a healthcare worker, being at least 18 years old, and currently working in one of the selected health clinics. We excluded potential subjects who were pregnant, bedridden, physically disabled, who had fevers or edema, or who were undergoing haemodialysis because those conditions can affect body fat and other index measurements.

A self-administered questionnaire was used to collect data on socio-demographic characteristics and anthropometric measurements of the healthcare workers. We used a Seca portable stadiometer, an Omron Karada scan/body composition scale (HBF375), and a stretchable measuring tape to measure height, weight, BMI, body fat percentage, and waist circumference.

BMI was calculated using the formula,

$$
\mathrm{BMI}=\text { body weight }(\mathrm{kg}) / \text { (height } \mathrm{x} \text { height }(\mathrm{m}) \text { ) }
$$

and classified according to WHO guidelines: underweight $\left(<18.5 \mathrm{~kg} / \mathrm{m}^{2}\right)$, normal $(18.5-24.9 \mathrm{~kg} /$ $\left.\mathrm{m}^{2}\right)$, overweight $\left(25.0-29.9 \mathrm{~kg} / \mathrm{m}^{2}\right)$, and obese $(\geq 30.0$ $\left.\mathrm{kg} / \mathrm{m}^{2}\right){ }^{22}$

Waist circumference was measured by placing the non-stretchable measuring tape horizontally midway between the lower part of the ribs and the iliac crest, based on the guidelines from the International Diabetes Federation (IDF) and WHO. ${ }^{23,24}$ The cut-off values recommended by IDF for South Asians $(>90 \mathrm{~cm}$ for men and $>80 \mathrm{~cm}$ for women) were used to classify waist circumference. ${ }^{23}$

Body fat percentage is the ratio of body fat mass to total body weight, and it can be determined through the electrical impedance of the body tissues. ${ }^{25}$ The table below shows the classifications of body fat 
percentages for males and females. ${ }^{26}$

\begin{tabular}{lll}
\hline Classification & Men & Women \\
\hline Low & Less than $10 \%$ & Less than $20 \%$ \\
Normal & $10 \%$ or more and & $20 \%$ or more and \\
& less than $20 \%$ & less than $30 \%$ \\
High & $20 \%$ or more and & $30 \%$ or more and \\
Very High & less than $25 \%$ & less than $35 \%$ \\
\hline
\end{tabular}

\section{Statistical analysis}

Data collected were analysed using IBM SPSS Statistics Standard Edition 20.0. Descriptive statistics were presented in terms of mean \pm standard deviation and percentage. The associations between categorical variables were analysed using a Chisquared test, and an independent sample t-test was used to compare the means of two groups. Multiple linear regression was performed to determine the predictors of obesity indices. All confidence intervals were set at a $95 \%$ probability level, and a p-value < 0.05 was considered statistically significant.

\section{RESULTS}

A total of 315 healthcare workers were invited to participate in the study. However, 54 were excluded due to non-response and incomplete questionnaires, making the final number of subjects 261 (82.9\%). Consent was obtained from all the healthcare workers before the study started. Table 1 shows the socio-demographic characteristics of the healthcare workers.

The majority of the healthcare workers were Malay $(80.9 \%)$, female $(83.9 \%)$, and married $(83.5 \%)$. All the recruited healthcare workers were between 21 and 59 years old, with a mean age of $36.8 \pm 8.0$ years. All of them received formal education, and more than half $(57.8 \%)$ received tertiary education. Half $(47.1 \%)$ of their household incomes fell between RM3001 and RM6000. Most $(80.9 \%)$ of the healthcare workers were categorised as "health service providers" and more than half $(66.3 \%)$ were "associates". Overall, $75.1 \%$ $(n=196)$ of the healthcare workers were satisfied with their health statuses, and only $24.9 \%(n=65)$ reported having certain health problems, which included hypertension (17.9\%), diabetes mellitus (11.9\%), and asthma (23.8\%).

The prevalence of overweight or obesity was $49.9 \%$, consisting of $28.4 \%$ overweight and $21.5 \%$ obese. The average BMI was $26.0 \pm 5.6 \mathrm{~kg} / \mathrm{m}^{2}$. Furthermore,
$51.0 \%$ had abdominal obesity with an average waist circumference of $85.0 \pm 13.8 \mathrm{~cm}$. Most $(79.6 \%)$ of the healthcare workers had a high to very high body fat percentage, the average of which was $32.8 \pm 6.2 \%$.

A Chi-squared test was used to determine the association between independent and dependent variables. Table 2 shows that older age was significantly associated with all the obesity indices: BMI $(p=<0.001)$, waist circumference $(p=<0.001)$, and body fat percentage $(p=<0.001)$. Healthcare workers with poor self-reported health status also showed significantly higher levels of BMI $(p=0.029)$, waist circumference $(p=0.002)$, and body fat percentage $(p=0.026)$. Healthcare workers with tertiary education had lower BMI $(p=0.008)$ and waist circumference $(p=0.003)$. Lastly, professionals had lower BMI $(p=0.04)$ than other healthcare workers did.

Table 1: Socio-demographic characteristics of the healthcare workers

\begin{tabular}{|c|c|c|c|}
\hline Variables & Categories & Frequency & Percentage \\
\hline \multirow[t]{2}{*}{ Ethnic } & Malay & 211 & 80.9 \\
\hline & Non-Malay & 50 & 19.1 \\
\hline \multirow[t]{2}{*}{ Sex } & Male & 42 & 16.1 \\
\hline & Female & 219 & 83.9 \\
\hline \multirow[t]{4}{*}{ Age (years) } & $20-30$ & 53 & 20.3 \\
\hline & $31-40$ & 137 & 52.5 \\
\hline & $41-50$ & 51 & 19.5 \\
\hline & $51-60$ & 20 & 7.7 \\
\hline \multirow[t]{2}{*}{$\begin{array}{l}\text { Educational } \\
\text { level }\end{array}$} & $\begin{array}{l}\text { Below } \\
\text { Tertiary }\end{array}$ & 110 & 42.1 \\
\hline & $\begin{array}{l}\text { Above } \\
\text { Tertiary }\end{array}$ & 151 & 57.9 \\
\hline \multirow{2}{*}{$\begin{array}{l}\text { Marital } \\
\text { status }\end{array}$} & Single & 35 & 13.4 \\
\hline & $\begin{array}{l}\text { Ever } \\
\text { married }\end{array}$ & 226 & 86.6 \\
\hline \multirow{5}{*}{$\begin{array}{l}\text { Monthly } \\
\text { household } \\
\text { income (RM) } \\
\text { Occupational } \\
\text { status }\end{array}$} & $\leq 3000$ & 92 & 35.2 \\
\hline & $3001-6000$ & 123 & 47.1 \\
\hline & $\geq 6000$ & 46 & 17.7 \\
\hline & Professionals & $\begin{array}{c}36 \\
172\end{array}$ & 13.8 \\
\hline & $\begin{array}{l}\text { Associates } \\
\text { Support } \\
\text { workers }\end{array}$ & $\begin{array}{l}1 / 3 \\
52\end{array}$ & $\begin{array}{l}66.3 \\
19.9\end{array}$ \\
\hline \multirow{8}{*}{$\begin{array}{l}\text { Self-reported } \\
\text { health status } \\
\text { Self-reported } \\
\text { health } \\
\text { problems }\end{array}$} & $\begin{array}{l}\text { Good } \\
\text { Poor }\end{array}$ & $\begin{array}{c}196 \\
65\end{array}$ & $\begin{array}{l}75.1 \\
24.9\end{array}$ \\
\hline & $\begin{array}{l}\text { Cardiovascular } \\
\text { Disease }\end{array}$ & 5 & 7.7 \\
\hline & Hypertension & 15 & 17.9 \\
\hline & $\begin{array}{l}\text { Diabetes } \\
\text { Mellitus }\end{array}$ & 10 & 11.9 \\
\hline & Osteoporosis & 3 & 3.6 \\
\hline & Gout & 3 & 3.6 \\
\hline & Asthma & 20 & 23.8 \\
\hline & Others & 28 & 33.3 \\
\hline \multirow{4}{*}{$\begin{array}{l}\text { Body Mass } \\
\text { Index (BMI) }\end{array}$} & Underweight & 12 & 4.6 \\
\hline & Normal & 119 & 45.6 \\
\hline & Overweight & 74 & 28.4 \\
\hline & Obese & 56 & 21.5 \\
\hline \multirow{2}{*}{$\begin{array}{l}\text { Waist } \\
\text { circumference }\end{array}$} & Acceptable & 128 & 49.0 \\
\hline & At risk & 133 & 51.0 \\
\hline \multirow{4}{*}{$\begin{array}{l}\text { Body fat } \\
\text { percentage }\end{array}$} & Low & 1 & 0.4 \\
\hline & Normal & 52 & 20.0 \\
\hline & High & 81 & 31.2 \\
\hline & Very High & 126 & 48.4 \\
\hline
\end{tabular}


Table 2: Association between socio-demographic characteristics and obesity indices among the healthcare workers

\begin{tabular}{|c|c|c|c|c|c|c|c|}
\hline \multirow{2}{*}{\multicolumn{2}{|c|}{ Variables }} & \multicolumn{2}{|c|}{$\begin{array}{c}\text { BMI }\left(\mathrm{kg} / \mathrm{m}^{2}\right) \\
\mathrm{n}(\%)\end{array}$} & \multicolumn{2}{|c|}{$\begin{array}{c}\text { WC (cm) } \\
\text { n (\%) }\end{array}$} & \multicolumn{2}{|c|}{$\begin{array}{l}\text { BF (\%) } \\
\mathrm{n}(\%)\end{array}$} \\
\hline & & $\begin{array}{l}\text { Normal } \\
<18.5- \\
24.9\end{array}$ & $\begin{array}{l}\text { Over- } \\
\text { weight } \\
\geq 25.0\end{array}$ & $\begin{array}{c}\text { Acceptable } \\
\text { Male } \leq 90 \\
\text { Female } \leq 80\end{array}$ & $\begin{array}{c}\text { At risk } \\
\text { Male }>90 \\
\text { Female > } \\
80\end{array}$ & $\begin{array}{c}\text { Acceptable } \\
\text { Male }<20 \\
\text { Female }<30\end{array}$ & $\begin{array}{c}\text { Unhealthy } \\
\text { Male } \geq 20 \\
\text { Female } \geq 30\end{array}$ \\
\hline \multirow[t]{2}{*}{ Gender } & $\begin{array}{l}\text { Male } \\
\text { Female }\end{array}$ & $\begin{array}{c}16(38.1) \\
115(52.5)\end{array}$ & $\begin{array}{l}26(61.9) \\
104(47.5)\end{array}$ & $\begin{array}{l}20(47.6) \\
108(49.3)\end{array}$ & $\begin{array}{l}22(52.4) \\
111(50.7)\end{array}$ & $\begin{array}{l}7(17.1) \\
46(21.0)\end{array}$ & $\begin{array}{c}34(82.9) \\
173(79.0)\end{array}$ \\
\hline & & \multicolumn{2}{|c|}{$p=0.087$} & \multicolumn{2}{|c|}{$p=0.840$} & \multicolumn{2}{|c|}{$p=0.566$} \\
\hline \multirow[t]{2}{*}{$\begin{array}{l}\text { Age (years } \\
\text { old) }\end{array}$} & $\begin{array}{l}<35 \\
\geq 35\end{array}$ & $\begin{array}{l}70(63.1) \\
61(40.7)\end{array}$ & $\begin{array}{l}41(36.9) \\
89(59.3)\end{array}$ & $\begin{array}{l}69(62.2) \\
59(39.3)\end{array}$ & $\begin{array}{l}42(37.8) \\
91(60.7)\end{array}$ & $\begin{array}{l}37(33.6) \\
16(10.7)\end{array}$ & $\begin{array}{c}73(66.4) \\
134(89.3)\end{array}$ \\
\hline & & \multicolumn{2}{|c|}{$\mathrm{p}=<0.001^{*}$} & \multicolumn{2}{|c|}{$\mathrm{p}=<0.001^{*}$} & \multicolumn{2}{|c|}{$p=<0.001^{*}$} \\
\hline \multirow[t]{2}{*}{ Ethnic } & $\begin{array}{l}\text { Malay } \\
\text { Non-Malay }\end{array}$ & $\begin{array}{l}100(47.4) \\
31(62.0)\end{array}$ & $\begin{array}{l}111(52.6) \\
19(38.0)\end{array}$ & $\begin{array}{l}98(46.4) \\
30(60.0)\end{array}$ & $\begin{array}{l}113(53.6) \\
20(40.0)\end{array}$ & $\begin{array}{l}40(19.0) \\
13(26.0)\end{array}$ & $\begin{array}{c}170(81.0) \\
37(74.0)\end{array}$ \\
\hline & & \multicolumn{2}{|c|}{$p=0.087$} & \multicolumn{2}{|c|}{$p=0.085$} & \multicolumn{2}{|c|}{$p=0.273$} \\
\hline \multirow[t]{3}{*}{ Income (RM) } & \multirow{3}{*}{$\begin{array}{l}\leq \mathrm{RM} 3000 \\
\mathrm{RM} 3001- \\
\mathrm{RM} 6000 \\
\geq 6001\end{array}$} & $\begin{array}{l}38(41.3) \\
66(53.7)\end{array}$ & $\begin{array}{l}54(58.7) \\
57(46.3)\end{array}$ & $\begin{array}{l}43(46.7) \\
60(48.8)\end{array}$ & $\begin{array}{l}49(53.3) \\
63(51.2)\end{array}$ & $\begin{array}{l}17(18.5) \\
24(19.5)\end{array}$ & $\begin{array}{l}75(81.5) \\
99(80.5)\end{array}$ \\
\hline & & $27(58.7)$ & $19(41.3)$ & $25(54.3)$ & $21(45.7)$ & $12(26.7)$ & $33(73.3)$ \\
\hline & & $p=c$ & 089 & $p=0$ & & $p=$ & 507 \\
\hline \multirow[t]{2}{*}{$\begin{array}{l}\text { Educational } \\
\text { Level }\end{array}$} & $\begin{array}{l}\text { Below } \\
\text { Tertiary } \\
\text { Tertiary } \\
\text { and above }\end{array}$ & $\begin{array}{l}45(40.9) \\
86(57.0)\end{array}$ & $\begin{array}{l}65(59.1) \\
65(43.0)\end{array}$ & $\begin{array}{l}42(38.2) \\
86(57.0)\end{array}$ & $\begin{array}{l}68(61.8) \\
65(43.0)\end{array}$ & $\begin{array}{l}17(15.5) \\
36(24.0)\end{array}$ & $\begin{array}{c}93(84.5) \\
114(76.0)\end{array}$ \\
\hline & & \multicolumn{2}{|c|}{$p=0.010^{*}$} & \multicolumn{2}{|c|}{$p=0.003^{*}$} & \multicolumn{2}{|c|}{$p=0.091$} \\
\hline \multirow[t]{2}{*}{ Marital Status } & $\begin{array}{l}\text { Single } \\
\text { Ever } \\
\text { Married }\end{array}$ & $\begin{array}{c}19(54.3) \\
112(49.6)\end{array}$ & $\begin{array}{c}16(45.7) \\
114(50.4)\end{array}$ & $\begin{array}{c}20(57.1) \\
108(47.8)\end{array}$ & $\begin{array}{c}15(42.9) \\
118(52.2)\end{array}$ & $\begin{array}{l}10(28.6) \\
43(19.1)\end{array}$ & $\begin{array}{c}25(71.4) \\
182(80.9)\end{array}$ \\
\hline & & \multicolumn{2}{|c|}{$p=0.603$} & \multicolumn{2}{|c|}{$p=0.303$} & \multicolumn{2}{|c|}{$p=0.196$} \\
\hline \multirow[t]{2}{*}{$\begin{array}{l}\text { Occupational } \\
\text { Status }\end{array}$} & $\begin{array}{l}\text { Professionals } \\
\text { Associates } \\
\text { Support } \\
\text { Workers }\end{array}$ & $\begin{array}{l}25(69.4) \\
83(48.0) \\
23(44.2)\end{array}$ & $\begin{array}{l}11(30.6) \\
90(52.0) \\
29(55.8)\end{array}$ & $\begin{array}{l}24(66.7) \\
81(46.8) \\
23(44.2)\end{array}$ & $\begin{array}{l}12(33.3) \\
92(53.2) \\
29(55.8)\end{array}$ & $\begin{array}{l}12(33.3) \\
31(18.0) \\
10(19.2)\end{array}$ & $\begin{array}{c}24(66.7) \\
141(82.0) \\
42(80.8)\end{array}$ \\
\hline & & \multicolumn{2}{|c|}{$p=0.040^{*}$} & \multicolumn{2}{|c|}{$p=0.071$} & \multicolumn{2}{|c|}{$p=0.113$} \\
\hline \multirow[t]{2}{*}{$\begin{array}{l}\text { Self- reported } \\
\text { Health status }\end{array}$} & $\begin{array}{l}\text { Good } \\
\text { No }\end{array}$ & $\begin{array}{l}106(54.1) \\
25(38.5)\end{array}$ & $\begin{array}{l}90(45.9) \\
40(61.5)\end{array}$ & $\begin{array}{l}107(54.6) \\
21(32.3)\end{array}$ & $\begin{array}{l}89(45.4) \\
44(67.7)\end{array}$ & $\begin{array}{l}46(23.6) \\
7(10.8)\end{array}$ & $\begin{array}{c}149(76.4) \\
58(89.2)\end{array}$ \\
\hline & & \multicolumn{2}{|c|}{$p=0.029^{*}$} & \multicolumn{2}{|c|}{$p=0.002^{*}$} & \multicolumn{2}{|c|}{$p=0.026^{*}$} \\
\hline
\end{tabular}

Pearson Chi-square test was performed

$p$-value $<0.05$, significant

Multiple linear regression showed that older age made the strongest significant contribution in predicting the dependent variable for all three indices (Tables 3-5). The BMI of the healthcare workers was predicted to increase by $0.130-0.403 \mathrm{~kg} /$ $\mathrm{m}^{2}$ with every unit increase in age. In contrast, the BMI for professionals such as doctors and pharmacists was predicted to be $2.458 \mathrm{~kg} / \mathrm{m}^{2}$ lower than associates.

\section{DISCUSSION}

In this study, the prevalence of overweight and obesity among the primary healthcare workers was 49.9\%, which is higher than the percentage reported in the NHMS 2015 (47.7\%) but slightly lower than in the MANS 2014 (50.9\%). Although these two studies surveyed people from all professions, the government and semi-government employee category in the NHMS 2015 appeared to have the highest prevalence of overweight (36.2\%) and obesity $(22.7 \%)$, which is in line with our results.

Even though the current overweight and obesity prevalence of the healthcare workers was not as high as previous studies have reported in other countries (especially South Africa), ${ }^{11,14,15}$ it is higher than most studies have reported in Asian countries, including a similar study from Malaysia. ${ }^{9,27-30}$ As a matter of fact, a recent review study reported that Malaysia is one of the fattest Asian countries, with $46.2 \%$ of Malaysians 20 years old and above being overweight or obese. ${ }^{31}$

In this study, $51.0 \%$ of the healthcare workers were at risk of having a high visceral adipose tissue, and 
$80 \%$ had high body fat percentages. This shows that BMI may not truly reflect the degree of fatness in every individual. In fact, studies have shown that Asians with lower BMI tend to have higher body fat percentages, facing higher cardiovascular risk compared to other populations. ${ }^{32,33}$ Similarly, only $20.4 \%$ of the healthcare workers in this study had low to normal body fat percentages, but $45.6 \%$ of the healthcare workers had normal BMI.

The high prevalence of overweight and obesity among the public healthcare workers may be due to their high level of commitment to their work, causing them to neglect their own health. ${ }^{34}$ Healthcare workers care for numerous patients every day, which may reduce their time to exercise and maintain a healthy body weight. According to $\mathrm{MOH}$, the doctorpopulation ratio in 2017 was $1: 632$ and the nursepopulation ratio was $1: 309 .^{35}$
In this study, socio-demographic characteristics such as age and self-reported health status were found to be associated with all the obesity indices. The healthcare workers aged 35 years old and above possessed a higher risk of becoming overweight or obese, according to abdominal obesity and unhealthy body fat percentage. As in the NHMS 2015, the prevalence of overweight and abdominal obesity increased with age starting from 30 years old until 60 years old. This finding was consistent with many other studies that showed that older healthcare workers were at a higher risk of becoming overweight and obese. ${ }^{12,34,36}$ Self-reported health status was another factor associated with all the obesity indices. Complications of obesity such as asthma, osteoarthritis, gout, and CVD may restrict the ability of healthcare workers to exercise and eventually lead to further weight gain. ${ }^{37}$

Table 3: Multiple linear regression analysis of factors associated with BMI

\begin{tabular}{lcccc}
\hline \multirow{2}{*}{ Variables } & \multicolumn{2}{l}{ BMI } & t-value & p-value \\
\cline { 2 - 5 } & $\begin{array}{l}\text { Unstandardized } \\
\text { coefficients }\end{array}$ & $\begin{array}{l}\text { Standardized } \\
\text { coefficients }\end{array}$ & & \\
\cline { 2 - 5 } & B & Beta & & \\
\hline (Constant) & 21.568 & & 13.246 & $<0.001$ \\
Age & 0.130 & 0.184 & 3.038 & 0.003 \\
$\begin{array}{l}\text { Occupational } \\
\text { status } \\
\text { (Professional) }\end{array}$ & -2.458 & -0.151 & -2.495 & 0.013 \\
\hline p-value< 0.05, significant & & & & \\
\hline
\end{tabular}

Table 4: Multiple linear regression analysis of factors associated with waist circumference

\begin{tabular}{lcccc}
\hline \multirow{2}{*}{ Variables } & \multicolumn{2}{l}{ WC } & t-value & D-value \\
\cline { 2 - 5 } & $\begin{array}{l}\text { Unstandardized } \\
\text { coefficients }\end{array}$ & $\begin{array}{l}\text { Standardized } \\
\text { coefficients }\end{array}$ & & \\
\cline { 2 - 5 } & $\mathrm{B}$ & Beta & & \\
\hline (Constant) & 70.138 & & 17.798 & $<0.001$ \\
Age & 0.403 & 0.233 & 3.848 & $<0.001$ \\
\hline
\end{tabular}

p-value $<0.05$, significant

Table 5: Multiple linear regression analysis of factors associated with body fat percentage

\begin{tabular}{|c|c|c|c|c|}
\hline \multirow{3}{*}{ Variables } & \multicolumn{2}{|l|}{$\mathrm{BF} \%$} & t-value & p-value \\
\hline & $\begin{array}{l}\text { Unstandardized } \\
\text { coefficients }\end{array}$ & $\begin{array}{l}\text { Standardized } \\
\text { coefficients }\end{array}$ & & \\
\hline & B & Beta & & \\
\hline (Constant) & 25.187 & & 14.362 & $<0.001$ \\
\hline Age & 0.208 & 0.268 & 4.460 & $<0.001$ \\
\hline
\end{tabular}

p-value $<0.05$, significant 
In addition, high educational level was associated with lower BMI and waist circumference. It was suggested that people with higher educational level usually work in the higher ranks of the occupational hierarchy, where they tend to put more focus on their physical appearances. ${ }^{38}$ No significant association was found in this study between educational level and body fat percentage; high body fat percentage was found among all the healthcare workers regardless of educational level. A study in Venezuela among participants from a subsidized food programme also showed similar findings in which body fat percentage was not influenced by educational level. ${ }^{39}$

Our analysis also showed that BMI was associated with occupational status. Professionals such as doctors, pharmacists, and dietitians were at a lower risk of becoming overweight and obese. As shown in other studies, professionals tend to have a higher awareness and knowledge of healthy lifestyles, and thus they are able to maintain a healthier body and body weight status. ${ }^{13,34}$

In contrast to many studies showing that females are more prone to becoming overweight, we found no significant association between genders in any of the obesity indices. However, the disproportionate distribution of male and female healthcare workers may have affected the findings. Nevertheless, as women predominate the Malaysian healthcare work force, the current sample represents the distribution suggested. ${ }^{40}$

Multivariate analysis showed that older age made the strongest significant contribution to all the obesity indices. As a person ages, their fat-free mass decreases due to physical inactivity, causing the fat mass to increase. The fat mass that accumulates in the abdominal part will have direct effects on the obesity indices. ${ }^{41}$ Professional was another predictor for a lower BMI. In this study, all the professionals had undergone tertiary education and had deep knowledge of health sciences. Therefore, it is expected that their awareness in taking care of their own body weight statuses is higher than that of other groups.

\section{Limitations}

There were some limitations found in this study. This study only involved primary healthcare workers from health clinics in Perak, and thus cannot be generalised to all the healthcare workers in Malaysia. Also, as this study is a cross-sectional study, the causal relationship between variables cannot be established. An intervention study could be performed so that the cause-effect relationship between various variables and obesity indices can be tested.

\section{CONCLUSIONS}

In conclusion, this study revealed that the prevalence of overweight and obesity among healthcare workers in Perak was high, with $49.9 \%$ being overweight or obese, $51 \%$ having high waist circumference, and $79.6 \%$ having high body fat percentage. These findings were higher than the general populations in Perak and Malaysia. Older age and professional were found to be the predictors for the obesity indices. This high prevalence of overweight and obesity requires immediate action, such as an intervention programme or healthy lifestyle campaign for healthcare workers.

\section{ACKNOWLEGEMENTS}

We acknowledge the support that we received from the Ministry of Health and Perak State Health Department for their approval to conduct this study. Special thanks to the Ethics Committee for Research Involving Human Subjects, Universiti Putra Malaysia (JKEUPM) for approving the research.

This Study was funded by the Research University Grant Scheme of the Universiti Putra Malaysia Vot No: 9599000 .

\section{REFERENCES}

1. Rampal L, Rampal S, Khor GL, et al. A national study on the prevalence of obesity among 16,127 Malaysians. Asia Pac J Clin Nutr. 2007;16(3):5616.

2. Lim KG. A Review of Adult Obesity Research in Malaysia. Med J Malaysia. 2016;71:1.

3. Ihab AN, Rohana A, Manan WW, et al. The coexistence of dual form of malnutrition in a sample of rural Malaysia. Int J Prev Med. 2013;4 (6):690.

4. World Health Organization. Obesity: preventing and managing the global epidemic: World Health Organization; 2000. 
5. Jensen MD, Ryan DH, Apovian CM, et al. 2013 AHA/ACC/TOS guideline for the management of overweight and obesity in adults: a report of the American College of Cardiology/American Heart Association Task Force on Practice Guidelines and The Obesity Society. J Am Coll Cardiol. 2014;63(25_PA).

6. World Health Organization. Obesity and Overweight, 2018 [Available from: http: / / www.who.int/mediacentre/factsheets/fs311/ en/. Retrieved on 3, June, 2018

7. Ministry of Health Malaysia. National Health \& Morbidity Survey 2015. Institute of Public Health; 2015.

8. Institute for Public Health. National Health and Morbidity Survey 2014: Malaysian Adult Nutrition Survey (MANS). 2014.

9. Mustafa J, Salleh NM, Isa ZM, et al. Overweight problem among primary health care workers in Suburban District of Hulu Langat, Selangor, Malaysia. Pakistan Journal of Nutrition. 2013;12 (3):291.

10. World Health Organization. The World Health Report 2006. 2006.

11. Onyebukwa CV. The prevalence of obesity and overweight among healthcare workers in Mafikeng Provincial Hospital: Stellenbosch: Stellenbosch University; 2011.

12. Phetla M, Skaal L. Perceptions of healthcare professionals regarding their own body weight in selected public hospitals in Mpumalanga Province, South Africa. SAMJ: South African Medical Journal. 2017;107(4):338-41.

13. Iwuala SO, Ayankogbe OO, Olatona FA, et al. Obesity among health service providers in Nigeria: danger to long term health worker retention? Pan African Medical Journal. 2015;22 (1).

14. Skaal L, Pengpid S. Obesity and health problems among South African healthcare workers: do healthcare workers take care of themselves? South African Family Practice. 2011;53(6):5637.

15. Goon D, Maputle M, Olukoga A, et al. Overweight, obesity and underweight in nurses in Vhembe and Capricorn districts, Limpopo. South Afr J Clin Nutr. 2013;26(3):147-9.

16. Perry L, Gallagher R, Duffield $C$. The health and health behaviours of Australian metropolitan nurses: an exploratory study. BMC nursing. 2015;14(1):45.

17. Bucher Della Torre S, Courvoisier D, Saldarriaga A, et al. Knowledge, attitudes, representations and declared practices of nurses and physicians about obesity in a university hospital: training is essential. Clinical obesity. 2018.

18. Motamed N, Sohrabi M, Poustchi H, et al. The six obesity indices, which one is more compatible with metabolic syndrome? A population based study. Diabetes \& Metabolic Syndrome: Clinical Research \& Reviews. 2017;11(3):173-7.

19. Zeng Q, He Y, Dong S, et al. Optimal cut-off values of BMI, waist circumference and waist: height ratio for defining obesity in Chinese adults. British Journal of Nutrition. 2014;112 (10):1735-44.

20. Zhang Z-q, Deng J, He L-p, et al. Comparison of various anthropometric and body fat indices in identifying cardiometabolic disturbances in Chinese men and women. PloS one. 2013;8 (8):e70893.

21. Janssen I, Heymsfield SB, Allison DB, et al. Body mass index and waist circumference independently contribute to the prediction of nonabdominal, abdominal subcutaneous, and visceral fat. Am J Clin Nutr. 2002;75(4):683-8.

22. World Health Organization. BMI Classification, 2006 [Available from: http: / /apps.who.int/ bmi/index.jsp?introPage=intro_3.html. Retrieved on 5 September 2016

23. Alberti KGMM, Zimmet $P$, Shaw J. Metabolic syndrome-a new world-wide definition. A consensus statement from the international diabetes federation. Diabetic medicine. 2006;23(5):469-80.

24. World Health Organization. Waist circumference and waist-hip ratio. Report of $a$ WHO Expert Consultation Geneva: World Health Organization. 2008:8-11.

25. Khalil SF, Mohktar MS, Ibrahim F. The theory and fundamentals of bioimpedance analysis in clinical status monitoring and diagnosis of diseases. Sensors. 2014;14(6):10895-928.

26. Nagamine $S$. The determination of fatness by skin fold measurement. J Jpn Phys Assoc. 1972;68:919-24.

27. Hwang L-C, Tsai C-H, Chen TH-H. Overweight and obesity-related metabolic disorders in hospital employees. J Formos Med Assoc. 2006;105(1):56-63.

28. Dorosty AR, Mehdikhani S, Sotoudeh G, et al. Perception of weight and health status among women working at Health Centres of Tehran. $J$ health Popul Nutr. 2014;32(1):58. 
29. Kim M-J, Son K-H, Park H-Y, et al. Association between shift work and obesity among female nurses: Korean Nurses' Survey. BMC Public Health. 2013;13(1):1.

30. Almajwal AM. Correlations of Physical Activity, Body Mass Index, Shift Duty, and Selected Eating Habits among Nurses in Riyadh, Saudi Arabia. Ecol Food Nutr. 2015;54(4):397-417.

31. Ng $M$, Fleming $T$, Robinson $M$, et al. Global, regional, and national prevalence of overweight and obesity in children and adults during 19802013: a systematic analysis for the Global Burden of Disease Study 2013. The Lancet. 2014;384(9945):766-81.

32. Misra A. Ethnic-specific criteria for classification of body mass index: a perspective for Asian Indians and American Diabetes Association Position Statement. Diabetes technology \& therapeutics. 2015;17(9):667-71.

33. Deurenberg-Yap M, Schmidt G, van Staveren WA, et al. The paradox of low body mass index and high body fat percentage among Chinese, Malays and Indians in Singapore. Int J Obes. 2000;24 (8):1011.

34. Kasu ES, Ayim A, Tampouri J. Prevalence of obesity among health workers in Kadjebi District of Ghana. Health Care. 2015;5(2).

35. Ministry of Health Malaysia. KKM Health Facts 2017. 2017.

36. Nelson CC, Wagner GR, Caban-Martinez AJ, et al. Physical Activity and Body Mass Index. Am J Prev Med 2014;46(3):S42-S51.

37. National Heart Lung and Blood Institute.

Overweight and Obesity, 2015 [Available from: https://www.nhlbi.nih.gov/health-topics/ overweight-and-obesity. Retrieved on 3 March, 2018

38. McLaren L. Socioeconomic status and obesity. Epidemiologic reviews. 2007;29(1):29-48.

39. Correa $M$, Herrera $M$, Hernández $P$, et al. Level of Education Is Related to Body Mass Index and Body Fat Percentage in Food Subsidy Program Users in Caracas, Venezuela. J Acad Nutr Diet 2013;113(9):A20.

40. Ministry of Health Malaysia. Human Resources for Health, Country Profiles 2015 Malaysia. 2016.

41. Yu D, Xian T, Wang L, et al. Analysis of body composition and resting metabolic rate of 858 middle-aged and elderly people in urban area of Beijing. Zhonghua liu xing bing xue za zhi= Zhonghua liuxingbingxue zazhi. 2018;39(5):6868. 